\title{
Rapid Removal of Symptomatic Trees Reduces Dutch Elm Disease Infection Rates
}

\author{
J. Veilleux, J. Leferink, and N.J. Holliday
}

\begin{abstract}
In the province of Manitoba, Canada, 14 communities were paired on the basis of size and location. From 2004 to 2010 in one member of each pair, rapid removal of American elm (Ulmus americana) trees that displayed symptoms of Dutch elm disease was practiced: newly symptomatic trees were removed within six weeks of symptom detection. The remaining member of each pair continued with autumn or winter removal of symptomatic trees. Treed urban study areas were selected in each community, and in 2008 an inventory of $U$. americana was taken in these areas. From this inventory and from records of tree removals, estimates of the number of living $U$. americana and prevalence of Dutch elm disease were made for each year from 2004 to 2010. Following the switch to rapid removal, the annual prevalence of Dutch elm disease in rapid removal communities was $1.5 \pm$ $0.2 \%$, significantly lower than in communities with autumn/winter removal $(3.1 \pm 0.4 \%)$. The study authors estimate that in similar areas the value of the elm resource after 10 years would be almost CAD $\$ 600,000 / \mathrm{km}^{2}$ greater if rapid removal rather than autumn/winter removal were practiced. Therefore, under conditions similar to those in these communities, rapid removal should be a component of management programs for Dutch elm disease.

Key Words. American elm; Hylurgopinus rufipes; Ophiostoma novo-ulmi; Sanitation; Tree Removal; Ulmus americana.
\end{abstract}

Dutch elm disease (DED) is a wilt disease of many species of Ulmus, and the two pandemics of this disease that have swept North America (Brasier 2000) have been responsible for the demise of the majority of American elm (U. americana) trees in many North American towns and cities. The causative agent of the second and more destructive pandemic is the fungal pathogen Ophiostoma novo-ulmi (Hintz et al. 1993; Brasier 2000). Although transmission of $O$. novo-ulmi between neighboring trees can occur through root grafts (Miller et al. 1969), the majority of transmission is the result of transfer of fungal spores by bark beetle vectors of the sub-family Scolytinae (Webber 2000). In North America, Scolytus multistriatus and Hylurgopinus rufipes are the two most important vector species (Strobel and Lanier 1981).

In Manitoba, although S. multistriatus has been collected (Buth and Ellis 1981), H. rufipes is by far the most important vector of DED (Hildahl and Wong 1965). Adults of $H$. rufipes overwinter in tunnels in the bark at the base of healthy U. americana (Anderson and Holliday 2003), and there is no evidence that larvae can survive the winter in Manitoba (Anderson 1996; Oghiakhe and Holliday, unpublished data). Brood galleries are constructed in recently dead or dying U. americana (Hildahl and Wong 1965; Bright 1976), which frequently are trees that are infected with, or have succumbed to, DED.

In Manitoba, DED presence was first confirmed in 1975 (Hildahl 1977), and since then a provincial integrated DED management program (Jeffrey 1982) has been active. In 2010, the program had a budget of CAD $\$ 1.3$ million and operated in 31 urban communities and in buffer zones surrounding the Cities of Winnipeg and Brandon, both of which have their own management programs. Main elements of the programs are area-wide sanita- tion of diseased and declining elms, regular insecticide applications to the basal part of healthy elm trees to control overwintering H. rufipes (Jin et al. 1996; Anderson and Holliday 2003; Oghiakhe and Holliday 2011), and regular pruning of dead wood.

More than $70 \%$ of the provincial DED management budget is dedicated to the sanitation program in which removals averaged 6,710 trees annually from 2004 to 2010 . The program involves the removal of all trees showing DED symptoms as well as hazard elm trees, defined as those with $\geq 40 \%$ deadwood. Yearly, between the end of June and late August, each community in the program was surveyed twice for elms displaying the DED symptoms of wilting and browning of foliage. Diagnosis of DED was confirmed if brown streaking of sapwood were seen in an infected branch. Infected trees were tagged and entered into a GIS-based database system so that they could be removed before April 1 of the following year (Manitoba Natural Resources 1981).

The effectiveness of sanitation for reducing DED prevalence (Miller et al. 1969; Van Sickle and Sterner 1976; Barger 1977) and its value for minimizing DED-related costs (Cannon et al. 1977) have been demonstrated, and some of these publications emphasize that tree removal should be prompt. Landwehr et al. (1982) found that the percentages of H. rufipes that were sporebearing were higher in Minnesota, U.S., cities where the interval from DED symptom detection to tree removal was longer, and suggested that trees showing symptoms in June should be removed within 90 days. In Manitoba, however, most removals are conducted during autumn and winter as fewer competing urban forestry operations are occurring at this time, and freezing of the ground reduces damage by heavy equipment used in removal operations. In Manitoba, DED symptoms normally first become 
visible in late June or July (Manitoba Conservation 2006), a time when overwintered females would be expected to have already selected dead or moribund trees for brood galleries and completed most of their oviposition (Kaston 1939; Finnegan 1957). Thus, delaying removal of previously healthy but now diseased trees until autumn or winter might be considered acceptable, as it could be assumed that there would be little oviposition in such trees in the year of symptom appearance. This assumption appears to be incorrect: in winter, last season's brood galleries in newly symptomatic trees showed evidence that adult beetles had emerged (Robbie-Draward 1995); and in newly symptomatic trees, $O$. novo-ulmi spore-bearing new adults that were ready to leave brood trees have been found in September and October (Oghiakhe and Holliday 2009). These findings suggest that there is a risk that autumn/winter removal could allow many sporebearing beetles from newly symptomatic trees to transmit the pathogen to healthy elm trees the following spring. However, it is not known whether $H$. rufipes adults that emerge in September and October can survive winter, and if so, what contribution such spore-bearing adults might make to DED transmission. The objective of the current study was to investigate in an operational setting whether rapid removal of symptomatic trees confers sufficient benefits to compensate for the additional logistic difficulties imposed by such a regime. To do this, pairs of communities were selected that were operating autumn/winter removal as part of the provincial DED management program. From 2004 to 2010, one of each community pair operated a rapid removal regime, while the other continued autumn/winter removal; and the annual DED prevalence under each removal regime was compared.

\section{METHODS}

In 2004, having received formal consent from each, 14 of the communities involved in the Manitoba provincial Dutch elm disease program were selected to take part in this study. Selected communities (Figure 1) were paired on the basis of geographic proximity, population size, and area under DED management (Table 1). Before the study, tree removals in all communities were performed in autumn/winter. One of each pair of communities was assigned to the rapid removal treatment, and this regime was practiced in these communities from 2004 until the end of the study in 2010. Surveys for DED were conducted in a similar manner in all communities and usually started whenever the first DED symptoms became visible, typically in late June. The first survey was usually completed by the first week in July, and in communities with rapid removal, symptomatic trees identified in the first survey were removed before the beginning of August. A second survey was conducted and generally completed by the end of the first week in August. In communities with rapid removal, trees that were first identified as symptomatic in the second survey would usually be removed during autumn and winter. All symptomatic trees in communities with autumn/winter removal, along with hazard trees in rapid removal communities, were removed during autumn and winter.

Aerial imagery was used to select a visually homogeneous, treed urban area within each community as a study area. These study areas were approximately square and their area averaged $0.98 \mathrm{~km}^{2}$, although there was considerable variation (Table 1). In each study area in May and June 2008, the U. americana of diameter at breast height $\geq 5 \mathrm{~cm}$ were counted. At the be-

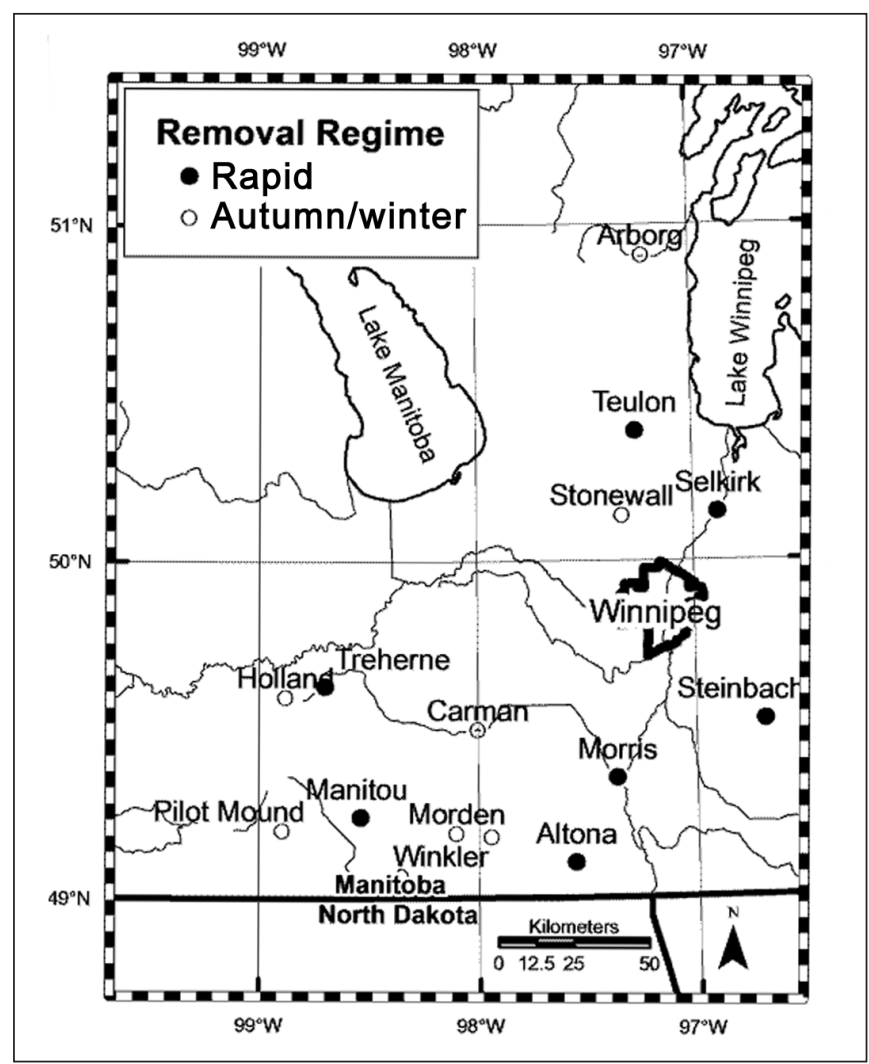

Figure 1. Map of south-central Manitoba, Canada, showing major rivers and the location of the study communities.

ginning of the period, buds of $U$. americana had not yet burst, but by the end trees were in full leaf. Consequently a variety of characteristics, including bud arrangement, bark color and texture, general tree shape, and leaves and flowers when present were used to distinguish $U$. americana from trees of other genera, and from its congener $U$. pumila. Mostly, walking along public access routes and in parks was enough to observe and identify $U$. americana, but in doubtful cases, binoculars were used or permission was obtained to walk in private backyards.

The counts of $U$. americana in each study area in 2008, together with records of removals of DED infected and hazard trees for the study areas from Manitoba Conservation, were the basis of estimates of $U$. americana numbers in other years between 2004 and 2010. To estimate the number of $U$. americana in each area in June 2007, the numbers of symptomatic and hazardous $U$. americana removed between June 2007 and June 2008 were added to the 2008 count. Similarly, sequential additions of numbers of removed trees to the estimated standing stock were used to estimate $U$. americana numbers in June of years 2004-2006; sequential subtractions of removed trees from counted or estimated standing stock were used to estimate $U$. americana numbers in June 2009-2010. Annual prevalence of DED for each study area for each year was calculated as the number of symptomatic trees detected in summer surveys expressed as a percentage of the estimated number of $U$. americana present in June of that year. For each study area, Manitoba Conservation provided data on the number of basal sprays applied for control of $H$. rufipes and on the number of illegally stored elm logs. 
The effect of the removal regime on the annual prevalence was assessed using linear mixed modeling (McLean et al. 1991). Values of annual prevalence of DED for 2005-2010 were considered dependent variables, as they could respond to the switch to rapid removal treatments in 2004. The annual prevalence in 2004 could not have responded to the shift to rapid removal, and so was considered a measure of preexisting conditions, and therefore a potential covariate. Attributes of study areas and communities that might confound the treatment effect or contribute to the model's precision were investigated by including them as potential covariates.

Linear mixed model analysis for a repeated measures design was carried out using Systat 13 (Systat 2009). Models were fit by restricted maximum likelihood (REML) and final models were selected on the basis of the Bayesian information criterion; on this basis, a variance components error covariance structure was determined to be most appropriate. Years and pairs were considered as random effects, and intercept, removal regime, and any covariates were considered to be fixed effects. The "subjects" of the repeated analysis were the 14 communities, repeated over years. Pilot analysis showed residuals to be non-normal; a square root transformation of annual prevalence effectively removed this problem and was applied before the final analyses were performed.

\section{RESULTS}

From 2004 to 2009, the rate of compliance with the desired time of removal of infected trees was relatively high in all communities (Table 1). Overall, communities assigned to the rapid removal regime removed $79 \pm 3 \%$ of infected $U$. americana before October 1 of the year in which symptoms were first observed. In communities assigned to autumn/winter removal, $92 \pm 6 \%$ of infected trees were removed on or after October 1. Communities varied considerably in the frequency with which basal insecticide applications for control of overwintering $H$. rufipes were made in the study area (Table 1). In most communities, when basal sprays were applied in the study area, the entire community received this treatment in the same year. However, in Steinbach and Selkirk, Manitoba, different portions of the community were treated in different years.

The average number of $U$. americana trees in the 14 study areas was 465 in 2008 (Table 1), equivalent to a mean density of
498 U. americana $/ \mathrm{km}^{2}$. Although every effort was made to use comparable study areas in each member of a community pair, it was not possible to identify $U$. americana from the aerial photographs used in the study area selection process, and so there was considerable variation in the number of $U$. americana in these areas. Annual prevalence of DED was calculated for all study areas for each year from 2004 to 2009. In 2010, no surveys for diseased trees were conducted in the communities of Arborg or Holland, and so prevalence data were available for only 12 communities. From 2005 to 2010, average annual prevalence (Figure 2) was invariably higher in autumn/winter removal communities than in those that switched to rapid removal in 2004. However, the same pattern of disease prevalence in rapid

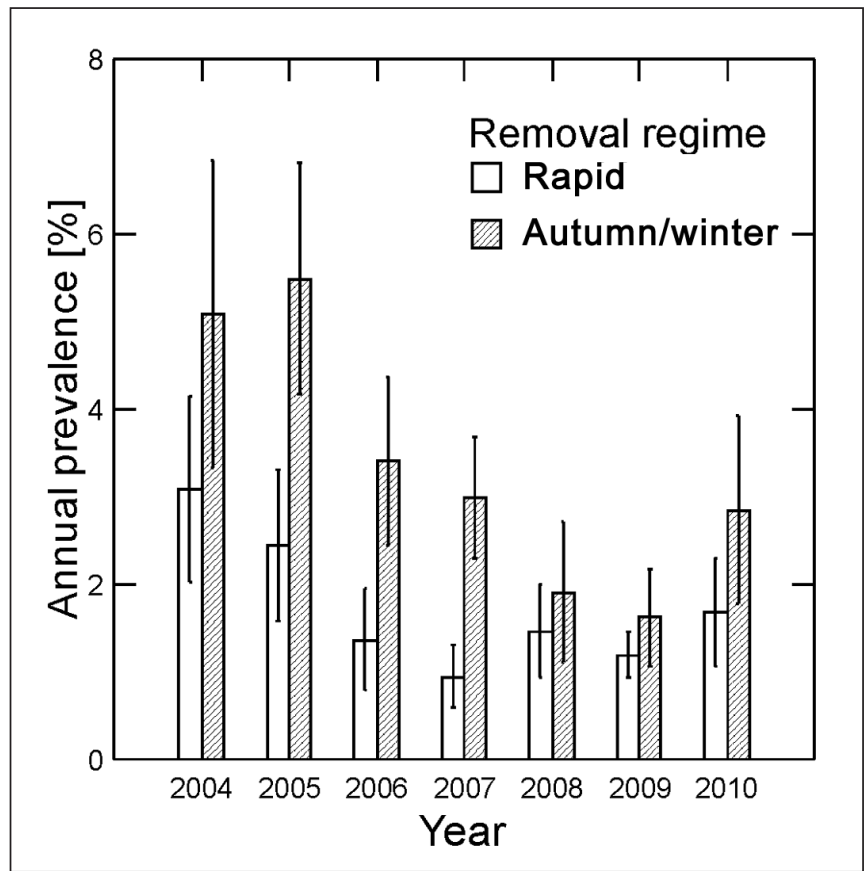

Figure 2. Annual mean $( \pm$ SEM) prevalence of Dutch elm disease infection in communities in relation to removal regime.

Table 1. Characteristics of communities and of study areas within them.

\begin{tabular}{|c|c|c|c|c|c|c|c|c|}
\hline \multirow[t]{2}{*}{ Pair } & \multicolumn{4}{|c|}{ Community } & \multicolumn{4}{|c|}{ Study area } \\
\hline & Name & $\begin{array}{l}\text { DED-managed } \\
\text { area }\left[\mathrm{km}^{2}\right]\end{array}$ & Removal regime & Area $\left[\mathrm{km}^{2}\right]$ & $\begin{array}{l}\text { Removals in } \\
\text { correct period } \\
{[\text { mean } \pm \text { SEM }(\%)]^{\mathrm{z}}}\end{array}$ & $\begin{array}{l}\text { Number of } \\
\text { basal sprays } \\
\text { 2004-2009 }\end{array}$ & $\begin{array}{l}\text { Number of } \\
\text { elm logs } \\
2004-2008\end{array}$ & $\begin{array}{l}\text { Number of } \\
\text { Ulmus americana } \\
\text { in } 2008\end{array}$ \\
\hline \multirow[t]{2}{*}{ A } & Carman & 4.24 & Autumn/winter & 0.76 & $100 \pm 0$ & 5 & 201 & 46 \\
\hline & Morris & 6.26 & Rapid & 0.96 & $80 \pm 8$ & 6 & 379 & 690 \\
\hline \multirow[t]{2}{*}{ B } & Winkler & 17.00 & Autumn/winter & 0.75 & $100 \pm 0$ & 4 & 357 & 305 \\
\hline & Steinbach & 27.03 & Rapid & 0.58 & $74 \pm 15$ & 4 & 155 & 600 \\
\hline \multirow[t]{2}{*}{$\mathrm{C}$} & Arborg & 3.41 & Autumn/winter & 0.83 & $100 \pm 0$ & 6 & 332 & 591 \\
\hline & Teulon & 3.16 & Rapid & 0.64 & $88 \pm 7$ & 2 & 51 & 410 \\
\hline \multirow[t]{2}{*}{$\mathrm{D}$} & Holland & 1.50 & Autumn/winter & 0.62 & $100 \pm 0$ & 3 & 96 & 234 \\
\hline & Treherne & 2.10 & Rapid & 1.11 & $72 \pm 19$ & 2 & 103 & 181 \\
\hline \multirow[t]{2}{*}{$\mathrm{E}$} & Pilot Mound & 2.81 & Autumn/winter & 0.52 & $83 \pm 17$ & 2 & 181 & 313 \\
\hline & Manitou & 2.74 & Rapid & 0.89 & $82 \pm 7$ & 6 & 121 & 463 \\
\hline \multirow[t]{2}{*}{$\mathrm{F}$} & Morden & 2.66 & Autumn/winter & 2.63 & $100 \pm 0$ & 3 & 967 & 1426 \\
\hline & Altona & 8.12 & Rapid & 0.68 & $90 \pm 10$ & 3 & 125 & 319 \\
\hline \multirow[t]{2}{*}{ G } & Stonewall & 6.40 & Autumn/winter & 0.67 & $57 \pm 18$ & 4 & 314 & 275 \\
\hline & Selkirk & 25.40 & Rapid & 2.11 & $69 \pm 13$ & 3 & 830 & 655 \\
\hline
\end{tabular}

${ }^{\mathrm{z}}$ Percentage of trees with symptoms of Dutch elm disease that were removed before October 1 in rapid removal communities, and on or after this date in autumn/winter removal communities. 
removal communities was also evident in 2004 , before the effect of the switch to rapid removal could have had an effect.

The initial linear mixed model analysis showed that the effect of rapid removal on annual prevalence for 2005-2010 was significant $\left(F_{1,68}=8.82, P=0.004\right)$, and that disease prevalence in 2004 was not a significant $\left(F_{1,68}=0.15, P=0.7\right)$ covariate. Nevertheless, because the pattern of disease prevalence in 2004 was similar to that which followed, the 2004 disease prevalence was retained as a covariate while the potential influence of other factors was explored. The response of annual prevalence to removal regime was robust and not greatly influenced either in magnitude or significance level by the addition, individually, of the following covariates to the initial model: DED managed area, area of study area, number of basal insecticide applications made from 2004 to 2009, number of basal applications made from 1999 to 2003, whether a basal application had been made in the previous year, whether a basal application had been made two years previously, number of illegally stored elm logs detected in the study area, number or square of the number of $U$. americana trees counted in the study area in 2008, and density or square of the density of $U$. americana in the study area in 2008. Consequently, the final model chosen did not include any of these covariates. The final model included pair and year as random effects and had removal regime as the only fixed effect; removal regime was highly significant $\left(F_{1,69}=10.70, P=0.002\right)$.

Overall, during the period $2005-2010$, the rapid removal member of a pair had a lower annual prevalence of DED than its corresponding autumn/winter removal community in $80 \%$ of the 40 possible comparisons. In this period, the average annual prevalence in rapid removal communities was $1.5 \pm 0.2 \%$, and that in autumn/winter removal communities was $3.1 \pm 0.4 \%$. The best estimate of the benefit of rapid removal was a reduction in annual prevalence of $1.56 \%$ with $95 \%$ confidence limits of $0.84 \%$ and $2.29 \%$.

\section{DISCUSSION}

The paired experimental design and the exploration of the potential influence of measurable covariates give confidence that the significant effect of timing of removal was not an artifact associated with some other variable. However, researchers were not able to eliminate all potential nuisance variables: possible effects of degree of isolation from wild sources of Dutch elm disease inoculum could not be removed either by the design or analysis.

All the study communities lie within the intensely farmed region of Manitoba, where most natural stands of $U$. americana occur in riverbanks and other moist areas that are unsuitable for agriculture (Scoggan 1957). There is no coordinated DED management of riverbank elms except where these trees lie within the provincial DED management areas, and so riverbank forests can be a source of DED inoculum, a habitat for vector beetles, and a potential corridor along which DED can be transmitted between communities. As the DED epidemic has progressed in Manitoba, fewer $U$. americana remain in riverbank communities, and many of the study communities are now quite isolated from external sources of infection. An exception is Selkirk, which is adjacent to a large area of wetland containing many diseased trees. It was not possible to derive an indicator for each community that would indicate the amount of inoculum from wild elms. Selkirk received the rapid removal regime and there were three rapid removal communities with rivers, compared with two autumn/ winter removal communities with rivers. Consequently, if lack of isolation from wetland elms were to increase DED prevalence, the authors would expect elevated prevalence in rapid removal communities, rather than the reduction that was observed in this study. Thus, the authors conclude the effect of isolation from wild sources of inoculum could not have produced the observed difference between rapid and autumn/winter removal, but rather could have reduced the magnitude of the effect that was observed.

This is the first long-term experimental study to show that DED prevalence can be reduced by rapid removal in regions where the dominant vector is $H$. rufipes, and the insect overwinters only in the adult stage. Under these circumstances, a major effect of rapid removal is to prevent the emergence of spore-bearing $H$. rufipes adults from brood galleries in newly symptomatic trees. By comparing experimental plots in Detroit, Michigan, U.S., Barger (1977) demonstrated that tree removal within 20 working days of symptom detection results in significantly lower DED prevalence than does removal during the following autumn and winter. In Detroit, both $H$. rufipes and $S$. multistriatus are important vector species and both overwinter as larvae and as adults. Consequently, emergence of spore-bearing adults from brood galleries can occur at most times of the growing season. Rapid removal would also reduce the likelihood of the pathogen transferring among neighboring trees through root grafts. In the current study, the rapid removal regime was applied only to trees in which symptoms appeared early in the season, yet this was sufficient to produce a consistent reduction in DED prevalence, perhaps because trees that exhibited symptoms late in the summer became attractive for brood gallery construction after the main period of $H$. rufipes oviposition. However, it cannot be assumed that DED-infected trees become targets for brood gallery construction only after visible DED symptoms appear, as $O$. novo-ulmi induces infected trees to produce volatiles that are attractive to H. rufipes (McLeod et al. 2005), and volatile production could precede the appearance of visual symptoms.

All communities were practicing an integrated disease management program for DED throughout the data collection phase of this study, and so annual prevalence was quite low in all communities. A similar program in Winnipeg resulted in an annual prevalence of about $2 \%$ over the first 30 years since DED was detected, compared with an estimated annual prevalence of $18 \%$ in similar cities with no management program (Domke 2005). Notwithstanding the generally low prevalence, there are considerable benefits from using rapid removal as a component of the management program. Over a 10 -year period, for areas similar to these study sites and the same $U$. americana density, the study authors estimate that the 498 trees $/ \mathrm{km}^{2}$ would decline to $427 / \mathrm{km}^{2}$ under a rapid removal regime, compared with $365 / \mathrm{km}^{2}$ if autumn/winter removal were employed. The current average cost of removal of a U. americana tree as part of Manitoba's provincial DED management program is about $\$ 350$, and the cost of planting and initial maintenance of a replacement boulevard tree for two years in Manitoba is $\$ 600$, giving a total average removal and replacement cost of $\$ 950$ per tree lost to DED. Using the trunk formula method (Council of Tree and Landscape Appraisers 1992), the estimated value of a boulevard tree in an urban environment in Manitoba is about $\$ 9,600$, when accounting for its aesthetic and other contributions. Thus, in 10 years, the retention of an additional 62 trees $/ \mathrm{km}^{2}$ through rapid removal would provide savings $/ \mathrm{km}^{2}$ in 
removal and replacement costs of about $\$ 59,000$ and prevent a decline in value of the elm resource of approximately $\$ 600,000$.

Against these savings must be set the costs associated with the damage caused to gardens and boulevards by operation of heavy equipment on unfrozen ground, and those of operating an intensive rapid removal program during the season when urban foresters are involved in many other activities. In the small communities in which the current study was performed, the rapid removal program was feasible because the number of trees to be removed was not large. However, in a city the size of Winnipeg, in which 4,000 to 6,000 infected trees need to be removed annually, there are insufficient resources to be able to remove all of them in a rapid removal program (D. Domke, pers. comm.). The researchers conclude that wherever possible, under the conditions of prairie Canada, rapid removal should be incorporated into integrated disease management programs for Dutch elm disease.

Acknowledgments. M. Barwinsky, City Forester, City of Winnipeg, provided estimates of tree values and of costs of replacement trees. We thank L. Lenz for assistance with tree identification, D. Domke for input on management practices, B. Rogala and S. Ibarra (University of Manitoba), and R. Eagle, D. Park, L. Christianson, D. Titterson, and S. Feuer (Manitoba Conservation) for technical assistance, and M. Barwinsky and I. Pines for reviewing an earlier version of the manuscript. Financial assistance was provided by the Sustainable Development Initiative (Province of Manitoba), Manitoba Conservation, the City of Winnipeg, the Natural Science and Engineering Research Council of Canada, and seventeen Manitoba Municipalities.

\section{LITERATURE CITED}

Anderson, P.L. 1996. Overwintering behaviour of the native elm bark beetle, Hylurgopinus rufipes (Eichhoff) (Coleoptera: Scolytidae), in Manitoba. M.Sc. thesis, Univ. of Manitoba, Winnipeg, Manitoba, Canada. 109 pp.

Anderson, P.L., and N.J. Holliday. 2003. Distribution of overwintering Hylurgopinus rufipes in trunks of American elm trees. Agricultural and Forest Entomology 5:137-144.

Barger, J.H. 1977. Improved Sanitation Practice for Control of Dutch Elm Disease. Forest Service research paper NE-386 of the Northeastern Forest Experiment Station, Forest Service, U.S. Department of Agriculture, Broomall, Pennsylvania, U.S. 4 pp.

Brasier, C.M. 2000. Intercontinental spread and continuing evolution of the Dutch elm disease pathogens, pp. 61-72. In: C.P. Dunn (Ed.). The Elms: Breeding, Conservation, and Disease Management. Kluwer Academic Publishers, Boston, Massachusetts, U.S.

Bright, D.E. 1976. The Bark Beetles of Canada and Alaska Coleoptera: Scolytidae. The Insects and Arachnids of Canada, Part 2, Publication 1572, Canada Department of Agriculture, Ottawa, Ontario, Canada. $241 \mathrm{pp}$.

Buth, J.L., and R.A. Ellis. 1981. Trapping elm bark beetles in the City of Winnipeg, with a new record for Scolytus multistriatus (Coleoptera: Scolytidae) in Manitoba. The Canadian Entomologist 113:263-264.

Cannon, W.N., J.H. Barger, and D.P. Worley. 1977. Dutch Elm Disease Control: Intensive Sanitation and Survey Economics. Forest Service research paper NE-387 of the Northeastern Forest Experiment Station, Forest Service, U.S. Department of Agriculture, Upper Darby, PA. 10 pp.

Council of Tree and Landscape Appraisers 1992. Guide for Plant Appraisal. 8th edition. International Society of Arboriculture, Savoy, Illinois, U.S. 103 pp.

Domke, D.A. 2005. 30 years of Dutch elm disease in Winnipeg. Urban Forester, Summer 2005:3.
Finnegan, R.J. 1957. Elm bark beetles in southwestern Ontario. The Canadian Entomologist 89:275-280.

Hildahl, V. 1977. Recognition and control of Dutch elm disease in the Prairie Provinces. Blue Jay 35:67-73.

Hildahl, V., and H.R. Wong. 1965. Distribution of the native elm bark beetle, Hylurgopinus rufipes (Eichhoff), in Manitoba and Saskatchewan. Proceedings of the Entomological Society of Manitoba 21: 36-38.

Hintz, W.E., R.S. Jeng, D.Q. Yang, M.M. Hubbes, and P.A. Horgen. 1993. A genetic survey of the pathogenic fungus Ophiostoma ulmi across a Dutch elm disease front in western Canada. Genome 36:418-426.

Jeffrey, C.A. 1982. Manitoba Dutch elm disease program development, pp. 121-128. In: E.S. Kondo, Y. Hiratsuka, and W.B.G. Denyer (Eds.). Proc. of Dutch elm disease symposium and workshop, October 5-9, 1981, Winnipeg, MB. Manitoba Natural Resources, Winnipeg, Manitoba, Canada.

Jin, H., G.R.B. Webster, N.J. Holliday, P.A. Pines, and A.R. Westwood. 1996. An elm bark beetle bioassay for residual efficacy of chlorpyrifos and cypermethrin used for the control of Dutch elm disease in Manitoba. Journal of Environmental Science and Health B 31: 751-761.

Kaston, B.J. 1939. The Native Elm Bark Beetle Hylurgopinus rufipes (Eichhoff) in Connecticut. Bulletin 420. Connecticut Agricultural Experiment Station, New Haven, Connecticut, U.S.

Landwehr, V., W. Phillipsen and M. Ascerno. 1982. An integrated approach to managing native elm bark beetle populations in Minnesota, pp. 454-465. In: E.S. Kondo, Y. Hiratsuka, and W.B.G. Denyer (Eds.). Proc. of Dutch elm disease symposium and workshop, October 5-9, 1981, Winnipeg, MB. Manitoba Natural Resources, Winnipeg, Manitoba, Canada.

Manitoba Conservation. 2006. Dutch elm disease. Accessed 06/23/2011. <www.gov.mb.ca/conservation/forestry/pdf/health/dutch_elm_ general.pdf>

Manitoba Natural Resources. 1981. A Municipal Guideline for the Control of Dutch Elm, Disease. Forestry Branch, Manitoba Natural Resources, Winnipeg, Manitoba, Canada.

McLean, R.A., W.L. Sanders, and W.W. Stroup. 1991. A unified approach to mixed linear models. The American Statistician 45:54-64.

McLeod, G., R. Gries, S.H. von Reuß, J.E. Rahe, R. McIntosh, W.A. König, and G. Gries. 2005. The pathogen causing Dutch elm disease makes host trees attract insect vectors. Proceedings of the Royal Society B 272:2499-2503.

Miller, H.C., S.B. Silverborg, and R.J. Campana. 1969. Dutch elm disease: relation of spread and intensification to control by sanitation in Syracuse, New York. Plant Disease Reporter 53:551-555.

Oghiakhe, S., and N.J. Holliday. 2009. Management of the Dutch elm disease vector Hylurgopinus rufipes in Manitoba through rapid removal of newly-symptomatic elm trees. Proceedings of the Entomological Society of Manitoba 64 (2008):10.

Oghiakhe, S., and N.J. Holliday. 2011. Evaluation of insecticides for control of overwintering Hylurgopinus rufipes (Coleoptera: Curculionidae). Journal of Economic Entomology 104:889-894.

Robbie-Draward, A. 1995. Elm Bark Beetle Small Sample Exploratory Survey. City of Winnipeg internal report. 6 pp.

Scoggan, H.J. 1957. Flora of Manitoba. National Museum of Canada Bulletin 140. Canada Department of Northern Affairs and National Resources, Ottawa, Ontario, Canada

Strobel, G.A., and G.N. Lanier. 1981. Dutch elm disease. Scientific American 245:56-66.

Systat 2009. Systat 13 Statistics II. Systat Software Inc., Chicago, Illinois, U.S. 502 pp. 
Van Sickle, G.A., and T.E. Sterner. 1976. Sanitation: A practical protection against Dutch elm disease in Fredericton, New Brunswick. Plant Disease Reporter 60:336-338.

Webber, J.F. 2000. Insect vector behaviour and the evolution of Dutch elm disease, pp. 47-60. In: C.P. Dunn (Ed.). The Elms: Breeding, Conservation, and Disease Management. Kluwer Academic Publishers, Boston, Massachusetts, U.S.

\section{J. Veilleux}

Department of Entomology

University of Manitoba

Winnipeg, Manitoba R3T 2N2, Canada

\section{J. Leferink \\ Manitoba Conservation - Forestry Branch \\ 200 Saulteaux Crescent \\ Winnipeg, Manitoba R3J 3W3, Canada}

\section{N.J. Holliday (corresponding author) \\ Department of Entomology \\ University of Manitoba \\ Winnipeg, Manitoba R3T 2N2, Canada \\ Neil_Holliday@UManitoba.CA}

Résumé. Dans la province du Manitoba au Canada, 14 municipalités ont été appariées sur la base de leur taille et de leur localisation. De 2004 à 2010 , sur un membre de chacune des paires, un abattage rapide des ormes d'Amérique (Ulmus americana) a été réalisé lorsque ces derniers présentaient des symptômes de maladie hollandaise de l'orme; les arbres avec des symptômes nouvellement apparus étaient abattus dans les six semaines suivant leur détection. Pour l'autre membre de chacune des paires, on poursuivait avec un abattage automnal ou hivernal des arbres symptomatiques. Des zones urbaines bien arborées ont été sélectionnées dans chacune des municipalités et, en 2008, un inventaire des U. americana a été réalisé. À partir de cet inventaire et des données d'abattage d'arbres, une estimation du nombre d'ormes d'Amérique vivants et de la prévalence de la maladie hollandaise de l'orme a été faite à chaque année entre 2004 et 2010. Suite au changement vers un abattage rapide, la prévalence annuelle de la maladie hollandaise de l'orme au sein des municipalités qui pratiquaient un abattage rapide était de $1,5 \pm 0,2 \%$, soit une proportion significativement plus faible que celles qui pratiquaient un abattage automnal ou hivernal $(3,1 \pm 0,4 \%)$. Les auteurs de cette étude estiment qu'avec des zones similaires en terme de valeur en ressource d'orme, les municipalités qui vont pratiquer un abattage rapide au lieu d'un abattage automnal/hivernal obtiendront une valeur supérieure de $600000 \$ / \mathrm{km}^{2}$ sur un horizon de 10 ans. De ce fait, sous des conditions à celles des municipalités étudiées, l'abattage rapide devrait constituer une composante d'un programme de gestion de la maladie hollandaise de l'orme.

Zusammenfassung. In der Provinz von Manitoba, Kanada, wurden 14 Kommunen von der Basis ihrer Größe und Lage gepaart. Von 2004 bis 2010 wurden in je einer der beiden Partnerkommunen die schnelle Beseitigung von mit der Holländischen Ulmenkrank befallenen Amerikanischen Ulmen (Ulmus americana) praktiziert: Bäume, die eine neue Infektion zeigten, wurden innerhalb von 6 Wochen komplett entfernt. Die andere Partnerkommune blieb bei der herkömmlichen Praxis der Herbst- oder Winterfällung von befallenen, kranken Bäumen. In jeder Kommune wurden Studiengebiete ausgewiesen und i 2008 wurden die Ulmen in diesen Regionen per Kataster erfasst. Aus diesem Kataster und den Aufzeichnungen über die gefällten und entfernten Bäume wurden Schätzungen über die Anzahl der lebenden Amerikanischen Ulmen und die Verbreitung der Holländischen Ulmenkrankheit für jedes Jahr im Zeitraum von 2004 bis 2010 vorgenommen. Wenn nach der Identifizierung der Symptome die prompte Beseitigung folgte, lag die jährli- che Verbreitung der Holländischen Ulmenkrankheit in den Kommunen, die diese Praxis verfolgten bei $1,5+/-0,2 \%$, deutlich niedriger als in den anderen Kommunen mit der Praxis der Herbst-/Winterfällung $(3,1$ +/- 0,4\%). Die Autoren dieser Studie schätzen, dass in vergleichbaren Gegenden der Wert an Ulmen-Resourcen nach 10 Jahren annähernd \$ $600.000 / \mathrm{km}^{2}$ größer wäre, wenn die Praxis der prompten Entfernung bevorzugt zum Einsatz käme. Daher sollte in Kommunen mit ähnlichen Bedingungen wie bei den untersuchten, die schnelle Entfernung mit der Ulmenkrankheit befallener Bäume als Komponente in die Pflegepläne integriert werden

Resumen. En la provincia de Manitoba, Canadá, 14 comunidades fueron apareadas con base en el tamaño y localización. Desde el 2004 al 2010 en un miembro de cada par se practicó la remoción rápida de olmos Americanos (Ulmus americana) que mostraron síntomas de la enfermedad holandesa del olmo (DED, por sus siglas en ingles). Los árboles sintomáticos fueron removidos dentro de las primeras seis semanas de detección del síntoma. Los miembros remanentes de cada par continuaron con remoción de otoño o invierno de árboles sintomáticos. Las aéreas urbanas tratadas en el estudio fueron seleccionadas en cada comunidad, y en 2008 se realizó un inventario de U. Americana en estas áreas. De este inventario y de los registros de la remoción de los árboles se estimaron los olmos vivos. U. Americana y la incidencia de DED se hicieron cada año de 2004 a 2010. Continuando el control de la remoción rápida, la incidencia anual de DED en la comunidades fue $1.5 \pm 0.2 \%$, significativamente más baja que en comunidades con remoción otoño/invierno $(3.1 \pm 0.4 \%)$. Los autores del estudio estiman que en áreas similares el valor del recurso olmo después de 10 años podría ser casi $\$ 600,000 / \mathrm{km} 2$ mayor, si la remoción rápida antes que la remoción de otoño/invierno fuera practicada. Por tanto, bajo condiciones similares a las de estas comunidades, la remoción rápida debería ser un componente de los programas de manejo para DED. 